\title{
1 John Neville Keynes
}

\author{
Heinrich Bortis
}

John Neville Keynes (1852-1949) has, in association with Alfred Marshall and his son John Maynard, decisively shaped the development of economic theory from the late nineteenth century to the early twenty-first century. He started lecturing on formal logic at Pembroke College (Cambridge) in the 1870s (Deane 2001, ch. 3), ${ }^{1}$ became a university lecturer in his preferred subject, political economy, within the framework of the moral sciences (ch. 5). The return of Alfred Marshall as professor of political economy severely limited his possibilities in this field and confined his teaching of political economy to an elementary course for Indian Civil Service candidates (Deane 1987). Given this, he increasingly turned to academic administration where he was associated with the reform of the moral sciences tripos 1885-97 and the creation of an economics tripos 1897-1908 (Deane 2001, ch. 8) to finally occupy the top bureaucratic post, University Registrar, from 1910 to 1925 (ch. 7). Let us now consider Neville Keynes's activities and assess, in a final section, the results of his direct and indirect influence on the development of economic theory.

\section{LECTURING AND WRITING ON FORMAL LOGIC}

Neville Keynes was not a charismatic lecturer. However, students 'found his methodical, clearheaded approach to formal logic particularly helpful when preparing for examinations. They were often explicitly grateful for the time and effort he put into giving advice and detailed explanations' (Deane 2001, p.115). In mid-1883 he felt sufficiently in control of his material on formal logic to write a students' manual which was published as Studies and Exercises on Formal Logic early in 1884. There were a few critical remarks, but on the whole the book was a great success. Marshall spoke of 'a beautiful specimen of thorough Cambridge work'. The fourth edition, again extensively rewritten, enlarged and further improved, came out in 1906 and became a classic to be reprinted twice in 1917 and 1928. Neville's 23-year-old son, Maynard, significantly remarked in a letter to his father: 'The worst of your book is that when one is reading it everything seems so hopelessly obvious and uncontroversial' (Deane 2001, pp. 115-22).

However, by its very nature, formal logic requires clear and uncontroversial exposition. The clear and methodological thinking acquired through teaching and writing on formal logic enabled Neville Keynes to write a crucially important book on the scope and method of political economy and to become a great university administrator who decisively shaped the academic climate at Cambridge. 


\section{THE MORAL SCIENTIST DEALING WITH THE SCOPE AND METHOD OF POLITICAL ECONOMY}

When Neville Keynes stepped out of his Pembroke fellowship in 1882, he had almost seven years of experience in teaching logic and political economy to moralists. For the next two years he carried a rather heavy intercollegiate lecture load. He lectured on logic and political economy to men reading for the moral sciences tripos and to Newnhamites; he coached Girtonians reading political economy and, from 1883 to 1893, he gave a specially adapted course on political economy to Indian Civil Service candidates. Moreover, he became an examiner in political economy and logic in various institutions and wrote his book on logic. Given this, Neville Keynes was appointed to the first and only newly created university lectureship in moral sciences in April 1884 (Deane 2001, pp. 113-15).

Neville Keynes intended to become the main teacher of political economy at Cambridge. However, Marshall returned to Cambridge (from Oxford) and became Professor of Political Economy in 1885 (he retired in 1908), and this option was no longer open. Nevertheless, Neville did not want to leave Cambridge, and refused all offers of posts elsewhere (including the offer of a Chicago chair in 1894), and increasingly devoted himself to university administration. Moreover, in mid-1885 he started to write a book on method which came out as The Scope and Method of Political Economy in 1891, a year after the publication of Marshall's Principles (Marshall 1890 [1930]). The starting point was the methodological debate that had set in during the great downswing of 1873-95, when unemployment increased and the situation of the workers worsened. This lead on to a critique of Ricardo's laissez-faire doctrine, unable to meet the socio-ethical problems of the industrial age. A methodological debate then developed facing historically minded and mathematical political economists. The basic problem, then 'was to reconstruct economic theory on lines which would command a consensus among leading economists' (Deane 2001, p. 132).

This reconstruction began with Marshall's inaugural lecture, which represented a manifesto for a progressive research programme, founded on a narrow core of pure, deductive, politically detached and mathematically rigorous science, the basis of which was laid in his Principles of Economics (July 1890). Keynes's Scope and Method of Political Economy (January 1891) represented the - complementary - ground-clearing contribution to the Marshallian research programme (Deane 2001, pp. 134, 136).

Chapter I of Keynes (1891) reviews the ongoing methodological debates. Section two is about 'the conception of political economy as a positive, abstract and deductive science', section three on 'the conception of political economy as an ethical, realistic and inductive science'. He then goes on to elaborate a synthesis by 'distinguishing three types of economic inquiry': first, 'a positive science', that is, 'a body of systematized knowledge concerning what is'; second, 'a normative or regulative science', that is, 'an art as systematized knowledge relating to criteria of what ought to be and concerned therefore with the ideal as distinguished from the actual'; and third 'an art as a system of rules for the attainment of a given end'.

This classification scheme permitted the economic theorist to insulate fundamental theorems from accusations of ideological bias, or ethical judgements, or relativity, as well as from failures in economic policies derived from these theorems. In effect, the normative science and the art of political economy provided a protective belt for the 
hard core of neoclassical theory that emerged from the marginal revolution. According to Keynes (1891, p. 52):

If political economy regarded from the theoretical standpoint is to make good progress it is essential that all extrinsic or premature sources of controversy should be eliminated; and we may be sure that the more its principles are discussed independently of ethical and practical considerations, the sooner will the science emerge from the controversial stage. (Deane 2001, pp. 139-40)

He was entirely in line with Alfred Marshall who claimed in his inaugural lecture: 'that part of economic doctrine which alone can claim universality, the principles to wit, has no dogmas. It is not a body of concrete truth but an engine for the discovery of concrete truth' (Keynes 1933a [1972], p. 196).

However, there are different engines, neoclassical, Marxian and classical-Keynesian, for example, and the selection of the engine is highly ideological, dependent on a social philosophy, a vision of man and society to wit. ${ }^{2}$ Yet, with the great Methodenstreit still going on in Germany and England above all, the logician Neville Keynes aimed at definitely clarifying the discussions on method to enable teachers and students to concentrate on contents. After the discussion on the transformation problem, and for ideological reasons, Ricardian and Marxian political economy were eliminated as possible engines for the discovery of concrete truth, although Marshall attempted to establish continuity between his new economics and the political economy of Ricardo and John Stuart Mill.

In a way, Marshall and Neville Keynes are right nevertheless: pure theory, based upon fundamental principles, must be universal and independent from space and time, that is, of historical realisations which gives rise to applied theory, and policy doctrines. With Marshall the fundamental principles are the marginal principle and the principle of supply and demand, embodied in his new economics, which still dominates the theoretical scene at the outset of the twenty-first century. Marshall's Principles became the most influential book in the history of economic theories through providing the basis for all neoclassical textbooks written since 1945. Through Alfred Marshall, neoclassical economic theory became a fortress to which Neville Keynes has provided important building blocks.

\section{TRIPOS REFORM AND CREATION OF AN ECONOMICS TRIPOS}

Neville Keynes's publications might give the impression that he was thinking mainly on logical and mathematical lines. This is entirely wrong. Already in summer 1873 he resisted his hitherto most respected mentors and decided to make the switch from mathematics - the then standard curriculum of Cambridge BA students - to morals (Deane 2001, p. 61). Keynes's propensity to put socio-economic phenomena into a wider context, also emerges from his position in the Tripos Reform. He 'was a product of the moral sciences tripos, a senior moralist of the $1873 / 83$ era, when political economy, moral plus political philosophy, logic and mental philosophy, were all compulsory and carried equal weight in the final result' (Deane 2001, p. 231). While Marshall was absent from Cambridge, his opponent Sidgwick masterminded, in 1883, a reform which resulted in an increase of the range and importance of philosophical subjects. On his return to Cambridge, Marshall 
tried to increase the weight of political economy within the moral sciences tripos from 1885 onwards (the year in which he became Professor of Political Economy) until the reform of 1897, which, however, increased the importance of political economy only marginally.

By the summer of 1897 it was plain to Marshall that there was insufficient support on the Moral Sciences Board for his personal mission to restructure the tripos on lines that could establish a starting-point for a modern school of economics at Cambridge. ... The way forward was evidently to create a separate tripos for economics and associated subjects:

[However,] as far as Keynes was concerned, raising the status of political economy in the university had never ranked high on his personal agenda. (Deane 2001, p. 234)

\section{Indeed,}

Keynes was an unreconstructed product of the pre-1883 moral sciences tripos. He held that, at the undergraduate level, economics should be taught alongside logic, psychology and ethics; and that specialized study of it was best reserved for mature students . . . He dreaded the establishment of a separate economics tripos because he rightly foresaw that it would lead to political economy being excluded from the moral sciences tripos altogether. (Deane 2001, p. 242, emphasis added)

In any case, a report proposing the creation of an economics tripos was passed by the Senate on 6 June 1903 by a majority of 28. Marshall had finally achieved his ambition (Deane 2001, pp. 244-5).

It was not long before Keynes's fears were realised and the philosophers took their revenge. At the first meeting of the Moral Sciences Board in October, McTaggart [a first class graduate from the 1888 moral sciences tripos who had already established a sound reputation as a philosopher (Deane 2001, 244)] announced his intention to move the exclusion of political economy from the tripos. His motion . . . was carried on October 26 [1903] after the defeat of Keynes's amendement .. . which would have retained political economy as an option for moralists. (Deane 2001, p. 245)

The separation of economics from the moral sciences was an event of paramount importance since it initiated the breaking up of the social and political sciences - the English moral sciences and the German Staatswissenschaften - and, as a consequence, an increasing specialisation in the course of the twentieth century until the present. We now have economists, a very few political economists, sociologists, political scientists, lawyers and so on. Within these social sciences, specialisation, based on individualism, goes on unimpeded at the expense of the social, conceiving of Man as a social individual living in a political society. (Incidentally, Margaret Thatcher put this admirably: there is no society, there are only individuals.)

Also, in 1903 a break-up occurred between Marshall and Neville Keynes. In his masterly biography of Marshall, Peter Groenewegen has a significant section entitled 'John Neville Keynes: from faithful to gradually disillusioned lieutenant' (1995, pp. 679-87). 'In the end, formal duty was all that remained of the relationship' (Groenewegen 1995, p. 687).

Neville Keynes thus remained a staunch moralist and, very importantly, his son Maynard inherited this quality to an extraordinary degree. This went not without saying. Indeed,

during Michaelmas term [1905], Keynes was attending Marshall's lectures on advanced economics, and his enthusiasm for the subject became such that his father recorded in November, 
'Maynard does a good deal of work for Marshall, who describes some of his answers as brilliant. I am afraid Marshall is endeavouring to persuade him to give up everything for Economics'. (Groenewegen 1995, pp. 553-4)

However, Maynard Keynes got quickly dissatisfied with economics and to the enormous regret of Marshall, abandoned his studies for the tripos. 'John Neville Keynes ... recorded with relief by the end of 1905 that Maynard was switching from economics to start preparation for the Civil Service Examinations' (Groenewegen 1995, p. 554). In the course of this preparatory work, Maynard Keynes read enormous quantities of books on philosophy, the history of economic ideas, general and economic history, as emerges from the unpublished Keynes Papers at King's College. Maynard Keynes was now definitely sailing in the direction of his father's cherished moral sciences and, indeed, far beyond.

\section{THE UNIVERSITY ADMINISTRATOR: SHAPING THE CAMBRIDGE INTELLECTUAL CLIMATE}

Neville Keynes was elected to the top bureaucratic post of Cambridge University, University Registrar, in 1910. He could now fully put to use his clear thinking and his tremendous capacities as an organiser, above all during the Great War 1914-18 (Deane 2001, ch. 10). However, Neville Keynes was much more than a most able administrator as emerges from a toast given by his son, Maynard, on the occasion of a lunch party at King's College in August 1942 to celebrate his parents' diamond wedding and his father's ninetieth birthday:

For thirty-three years he was one of the best administrators there ever was . . . Perfect order and accuracy without a shadow of pedantry or red tape, the machine existing for the sake of the University ... He helped to create a framework within which learning and science and education could live and florish without feeling restraint or a hampering hand. And he combined this with himself pursuing learning and science and education. (Deane 2001, p. 307)

Given this, Neville Keynes decisively shaped the Cambridge intellectual climate. He greatly contributed to creating the ideal of the medieval university: the Cambridge colleges and the university as a community of dons and students in the uncompromising search for truth. This climate of total open-mindedness and the judicious influence on Maynard's intellectual development produced extraordinary results.

\section{THE RESULT: THE YEARS OF HIGH THEORY, AND BEYOND}

The results were outstanding: The Years of High Theory 1926-1939 (Shackle 1967) with Maynard Keynes as the main protagonist, greatly helped by Piero Sraffa, and important theoretical developments after 1945.

The Years of High Theory represent a highly important, perhaps the most important, period in the entire history of economic theories, very briefly sketched in Bortis (2016). A twin revolution against the neoclassical citadel built up by Marshall and Neville Keynes took place. Maynard Keynes set out to elaborate a Monetary Theory of Production (Keynes 1933b [1973]) elaborating a new, anti-Marshallian theory of output 
and employment grounded on the investment multiplier (exhibiting the principle of effective demand), as well as a new theory of money and interest; most importantly, Keynes showed that an equilibrium level of employment with persistent involuntary unemployment was possible. Piero Sraffa initiated a fundamental attack upon Marshall's theory of value and distribution, resulting, in 1960, in his prices of production, with the determination of the profit rate being based on the surplus principle; the essence of the prices of production is represented by labour values (Bortis 2016, pp. 66-7). Piero Sraffa thus decisively contributed to reviving the classical approach in economic theory.

Moreover, since his intellectual break with Marshall at the end of 1905, Maynard Keynes has subsequently become a fully fledged moral scientist, more complete and profound as the staunch moralist Neville Keynes could ever have conceived. This forcefully emerges from two splendid books making use of unpublished papers at the Keynes archives in King's College, that is, Fitzgibbons (1988) and O'Donnell (1989).

After the Second World War, two great strands of thought grow out of the Years of High Theory: post-Keynesian economics, based on Maynard Keynes and Michał Kalecki, and neo-Ricardianism, grounded upon Sraffa. Led by Luigi Pasinetti, the neo-Ricardians undertook a large-scale victorious attack upon the neoclassical-Marshallian fortress in the course of the capital-theory debate in the early 1960s (Harcourt 1972). In spite of this success, the neoclassicals continued to dominate the theoretical scene and Maynard Keynes was even imprisoned in the neoclassical fortress, with the prisoner becoming a Walrasian disequilibrium theorist (Bortis 2016, pp. 51-4).

The main reason for these unfortunate developments is that the excellent pieces of post-Keynesian and neo-Ricardian economics do not represent a fully fledged theoretical system based on an explicitly formulated social philosophy and on fundamental theoretical principles: the labour value principle and the surplus principle of distribution as well as the principle of effective demand. These principles are essential to build up the pure theory of value and distribution, and of output and employment, which would be part of a classicalKeynesian monetary theory of production. (In this context it is important to note that, in classical-Keynesian pure theory, the independent variables in all equations as well as the trend and cycle variables are all independent of each other (Bortis 2016, pp. 64-72); this would not be the case in applied theory.) A precise system of pure theory of a monetary production economy is necessary to be able to elaborate an open-ended set of applied theories to explain most differing socio-economic real-world phenomena. Such a classical-Keynesian system of political economy would represent the counterpart to Alfred Marshall's (1890 [1930]) Principles of Economics (see Bortis 2016 for economics and political economy).

This theoretical technique - pure cum applied theory - was put to use by Maynard Keynes in his Treatise on Money (1930, vol. I, The Pure Theory of Money and vol. II, The Applied Theory of Money) and in his General Theory (1936) where he distinguishes

between the logical theory of the multiplier, which holds good continuously, without time-lag, at all moments of time [the multiplier principle is prior to its historical realizations in space and time], and the consequences of an expansion in the capital-goods industries which take gradual effect [in space], subject to time-lag and only after an interval [hence in historical time]. (Keynes 1936, p. 122)

The 'pure cum applied theory technique' goes, in modified form though, back to Neville Keynes's (1891) Scope and Method of Political Economy. This closes the wide circle of 
Neville Keynes's direct and indirect influence on the development of economic theory in the stormy times from the end of the nineteenth century to the outset of the twenty-first century. The subtitle of Phyllis Deane's (2001) splendid biography of Neville Keynes - $A$ Beacon in the Tempest - is thus very aptly chosen.

\section{NOTES}

1. All direct and indirect quotations are from Deane (2001) if not otherwise indicated.

2. Geoffrey Harcourt of the University of New South Wales made me aware of this issue.

\section{REFERENCES}

Bortis, H. (2016), 'The history of economic theories', in L.-P. Rochon and S. Rossi (eds), An Introduction to Macroeconomics: A Heterodox Approach to Economic Analysis, Cheltenham, UK and Northampton, MA, USA: Edward Elgar, pp. 42-75.

Deane, P. (1987), 'Keynes, John Neville', in J. Eatwell, M. Milgate and P. Newman (eds), The New Palgrave: A Dictionary of Economics, vol. 3, London: Macmillan, p. 42.

Deane, P. (2001), The Life and Times of J. Neville Keynes: A Beacon in the Tempest, Cheltenham, UK and Northampton, MA, USA: Edward Elgar.

Fitzgibbons, A. (1988), Keynes Vision: A New Political Economy, Oxford: Clarendon Press.

Groenewegen, P. (1995), A Soaring Eagle: Alfred Marshall 1842-1924, Aldershot, UK and Brookfield, VT, USA: Edward Elgar.

Harcourt, G.C. (1972), Some Cambridge Controversies in the Theory of Capital, Cambridge: Cambridge University Press.

Keynes, J.M. (1930), A Treatise on Money, 2 vols, London: Macmillan.

Keynes, J.M. (1933a), Essays in Biography - Alfred Marshall, repr. 1972 in D.E. Moggridge (ed.), The Collected Writings of John Maynard Keynes, vol. X, London and Basingstoke: Macmillan, pp. 161-231.

Keynes, J.M. (1933b), A Monetary Theory of Production, repr. 1973 in D.E. Moggridge (ed.), The Collected Writings of John Maynard Keynes, vol. XIII, London: Macmillan, pp. 408-11.

Keynes, J.M. (1936), The General Theory of Employment, Interest and Money, London: Macmillan.

Keynes, N. (1884), Studies and Exercises in Formal Logic, London: Macmillan.

Keynes, N. (1891), The Scope and Method of Political Economy, London: Macmillan.

Marshall, A. (1890): Principles of Economics, 8th edn 1930, London: Macmillan

O'Donnell, R.M. (1989), Keynes: Philosophy, Economics and Politics: The Philosophical Foundations of Keynes' Thought and Influence on his Economics and Politics, London: Macmillan.

Shackle, G.L.S. (1967), The Years of High Theory - Invention and Tradition in Economic Thought 1926-1939, Cambridge: Cambridge University Press.

Sraffa, P. (1960), Production of Commodities by Means of Commodities, Cambridge: Cambridge University Press. 